WSRC-TR-98-00297, Revision 0

\title{
HYDROGEN GENERATION RATE DURING MELTER FEED PREPARATION OF TANK 42 SLUDGE AND CST IN THE DEFENSE WASTE PROCESSING FACILITY (DWPF) (U)
}

D. P. Lambert

P. R. Monson

Westinghouse Savannah River Company Savannah River Site

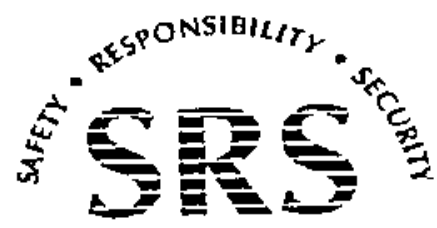

PREPARED FOR THE U.S. DEPARTMENT OF ENERGY UNDER CONTRACT NO. DE-AC09-96SR18500 
This document was prepared in conjunction with work accomplished under Contract No.

DE-AC09-96SR18500 with the U.S. Department of Energy.

\section{DISCLAIMER}

This report was prepared as an account of work sponsored by an agency of the United States Government. Neither the United States Government nor any agency thereof, nor any of their employees, makes any warranty, express or implied, or assumes any legal liability or responsibility for the accuracy, completeness, or usefulness of any information, apparatus, product or process disclosed, or represents that its use would not infringe privately owned rights. Reference herein to any specific commercial product, process or service by trade name, trademark, manufacturer, or otherwise does not necessarily constitute or imply its endorsement, recommendation, or favoring by the United States Government or any agency

thereof. The views and opinions of authors expressed herein do not necessarily state or reflect those of the United States Government or any agency thereof.

This report has been reproduced directly from the best available copy.

Available for sale to the public, in paper, from: U.S. Department of Commerce, National Technical Information Service, 5285 Port Royal Road, Springfield, VA 22161, phone: (800)

553-6847, fax: (703) 605-6900, email: orders@ntis.fedworld.gov online ordering: http://www.ntis.gov/ordering.htm

Available electronically at http://www.doe.gov/bridge

Available for a processing fee to U.S. Department of Energy and its contractors, in paper, from: U.S. Department of Energy, Office of Scientific and Technical Information, P.O. Box 62, Oak Ridge, TN 37831-0062, phone: (865 ) 576-8401, fax: (865) 576-5728, email: reports@ adonis.osti.gov 
WSRC-TR-98-00297, Revision 0

Distribution Category: To Be Determined

Keywords: DWPF, CPC, CST, Sludge,

Tank 42

Retention: Permanent

HYDROGEN GENERATION RATE DURING MELTER FEED PREPARATION OF TANK 42 SLUDGE AND CST IN THE DEFENSE WASTE PROCESSING FACILITY (DWPF) (U)

Publication Date: September 21, 1998 
$\rightarrow \operatorname{tin}=7$ D. P. Lambert, Author

Paul R. gmonson

P. R. Monson, Author

(i) E. Crines

W.E. Daniel, Technical Reviewer

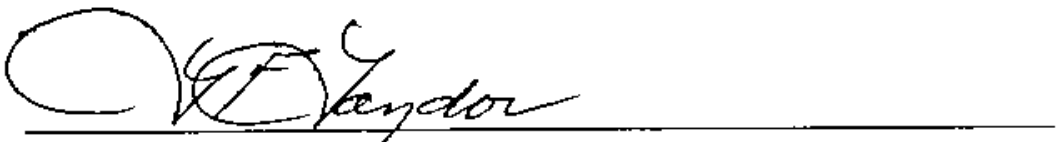

L. F. Landon, Mangger

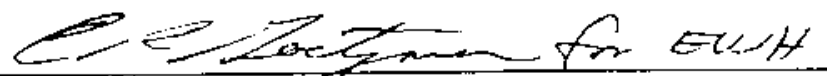

E. W. Holtzscheiter, Defense Waste Processing Technology

$\frac{\text { J. V. Carter, Salt Disposition Flowsheet Team }}{\text { Tem }}$

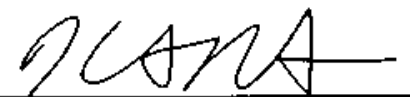

K. J. Rueter, Salt Disposition Systems Engineering Team

$$
\frac{9-23-7 y}{\text { Date }}
$$

$$
\frac{q-23-98}{\text { Date }}
$$

$\frac{9-2.568}{\text { Date }}$

$\frac{9 / 23 / 98}{\text { Date }}$
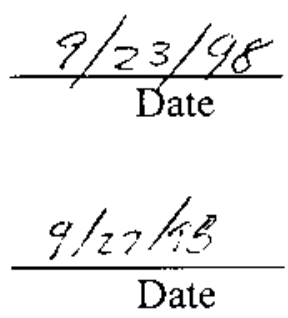

$$
\frac{9 / 28 / 98}{\text { Date }}
$$

Westinghouse Savannah River Company

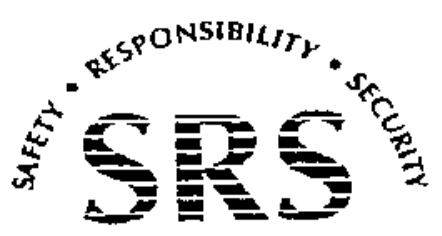

PREPARED FOR THE U.S. DEPARTMENT OF ENERGY UNDER CONTRACT NO. DE-AC09-96SR18500 


\section{EXECUTIVE SUMMARY}

The salt disposition team requested ITS to assess the effect of crystalline silicotitanate (CST) resin with sludge in the DWPF Chemical Process Cell (CPC) on the maximum hydrogen generation rate produced during the DWPF melter feed preparation processes ${ }^{1}$ (Issue 21 , HLETAR-98060). The testing requested by this TAR was scoping in nature. The melter feed produced during these experiments was subsequently used in a settling study (Issue 13, HLETAR-98060).

CST is one of four process options under evaluation to the current In-Tank precipitation process. CST is a non-elutable resin used to remove ${ }^{137} \mathrm{Cs}$ from the supernate fraction of SRS High Level Waste. The CST would be combined with the sludge in the SRAT (to replace the PHA that is currently part of DWPF's coupled flowsheet). Frit would then be added to the SRAT product as in a typical DWPF SME cycle.

Testing was completed using a non-radioactive Tank 42 sludge simulant. A $1 / 10,000^{\text {th }}$ scale laboratory setup was used and the results then scaled for DWPF operations. HM levels (maximum expected concentrations) of noble metals and mercury were added to the sludge to maximize the hydrogen generation. The targeted CST concentration would result in $10 \mathrm{wt} \%$ CST in the glass. The CST was not loaded with noble metals.

Major conclusions from the testing are:

- The maximum SRAT hydrogen generation rate was $0.40 \mathrm{lb} / \mathrm{hr}$ in the coarse CST run, based on a 6000 gallon DWPF sludge batch. Excluding the hydrogen spike at the onset of boiling, maximum hydrogen generation rate was $0.34 \mathrm{lb} / \mathrm{hr}$. The DWPF limit is $0.65 \mathrm{lb} / \mathrm{hr}$.

- The maximum SME hydrogen generation rate was $0.22 \mathrm{lb} / \mathrm{hr}$ based on a 6000 gallon DWPF sludge batch. Excluding the hydrogen spike at the onset of boiling , maximum hydrogen generation rate was $0.16 \mathrm{lb} / \mathrm{hr}$. The DWPF limit is $0.23 \mathrm{lb} / \mathrm{hr}$.

- The runs containing CST produced more hydrogen than the sludge-only run ( $40 \%$ in the SRAT cycle and $10 \%$ in the SME cycle based the first week's runs).

- The CST particle size does not affect hydrogen generation.

- Foaming was significant during the runs (including the sludge-only run). More frequent antifoam additions were necessary to control the foaming. 
Westinghouse Savannah River Company

Savannah River Technology Center

WSRC-TR-98-00297, Revision 0

\section{Recommendations for Future Work}

Future work should consider completing experiments to test the following items:

1. Pre-treat the CST by loading the CST with a salt solution simulant to produce spent CST resin loaded with noble metals.

2. Continue studying the hydrogen generation. Develop a relationship to predict the generation rate of hydrogen during processing with CST. Confirm the differences between the first week's and second week's runs. Determine whether the hydrogen measured during the onset to boiling is a realistic peak. 
Westinghouse Savannah River Company

Savannah River Technology Center

WSRC-TR-98-00297, Revision 0

Table of Contents

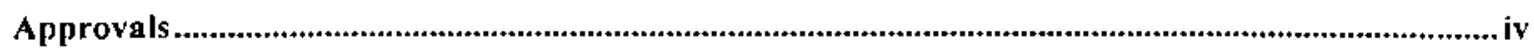

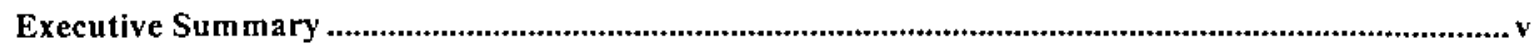

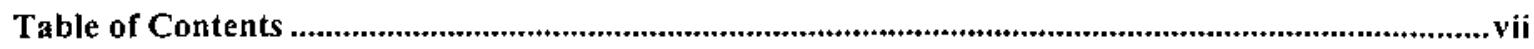

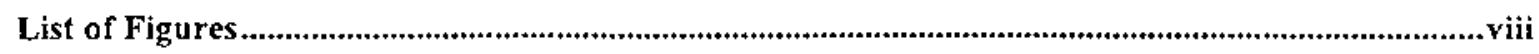

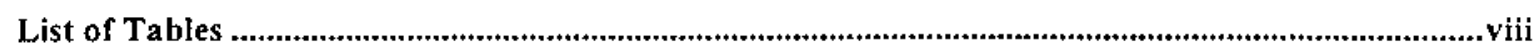

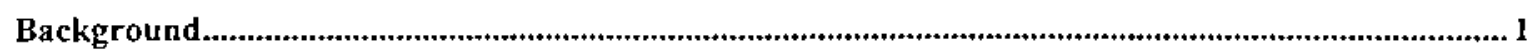

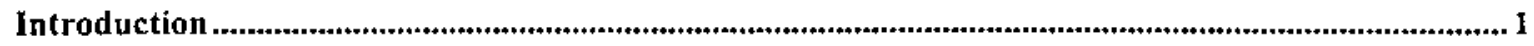

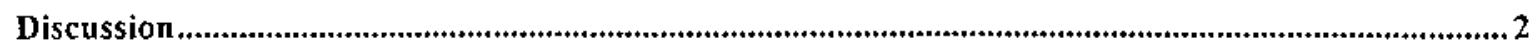

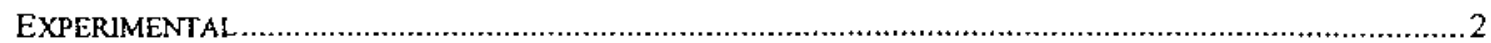

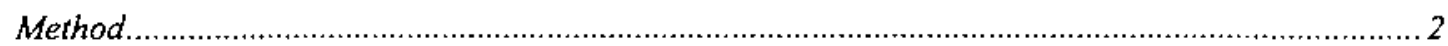

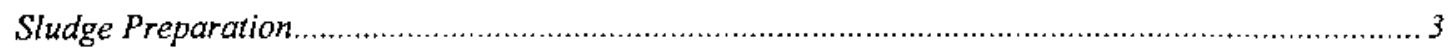

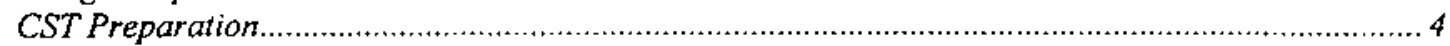

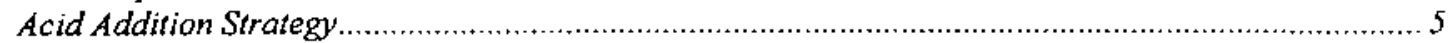

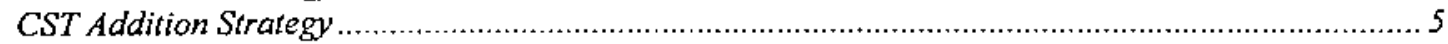

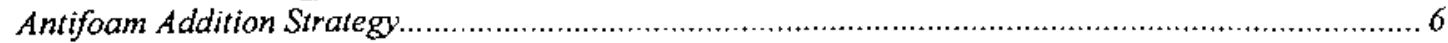

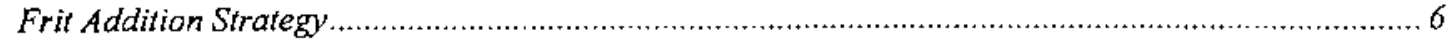

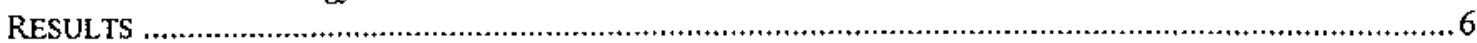

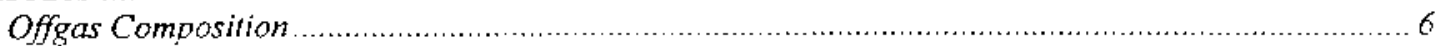

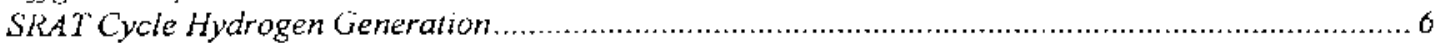

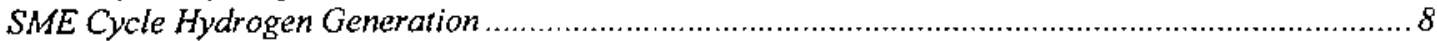

Discussion of Hydrogen Generation.............................................................................. 10

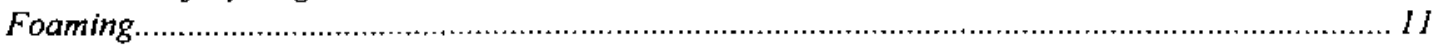

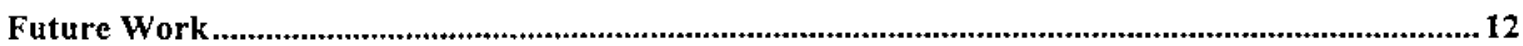

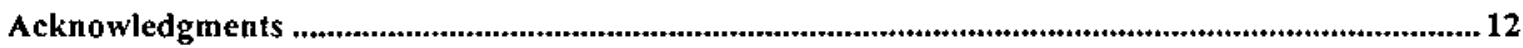

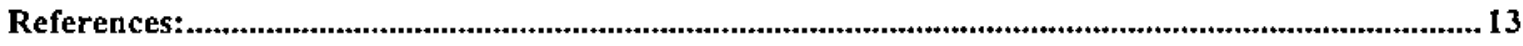

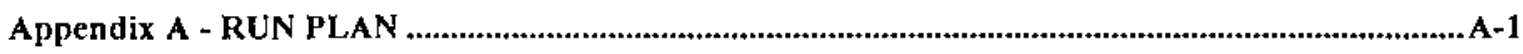

Appendix B - Scope Document Summarizing Planned Testing ........................................................... B-1 
Westinghouse Savannah River Company

Savannah River Technology Center

\section{LIST OF FIGURES}

Figure 1 - CST Particle Size ...................................................................................

Figure 2 - SRAT Cycle Hydrogen Generation ..............................................................

Figure 3 - SME Cycle Hydrogen Generation ………................................................9

\section{LIST OF TABLES}

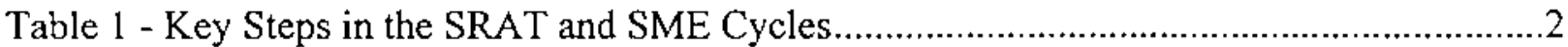

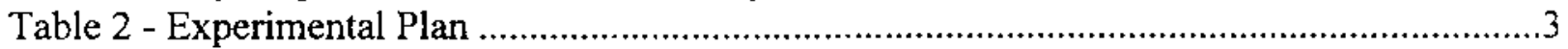

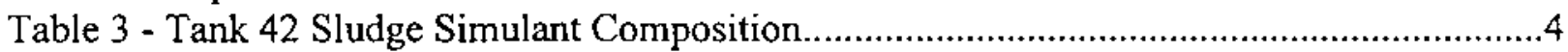

Table 4- SRAT Cycle Hydrogen Generation Summary ............................................................

Table 5- SME Cycle Hydrogen Generation Summary ..............................................................

Table 6 - ICP Analysis of SRAT Product Samples for Noble Metals ........................................1 I

Table 7 - Preparation Of Tank 42 Sludge For All Experiments (Trim Chemicals Missing)... A-1

Table 8 - Trim Chemical Addition For Each Batch …….............................................. A-2

Table 9 - Batching Calculation for Coupled Sludge/CST Experiment .................................. A-3

Table 10- Scaling Calculation For Coupled Sludge/CST Experiment .................................. A-4 


\section{BACKGROUND}

The Defense Waste Processing Facility began processing radioactive Tank 51 Sludge in 1996. Because of delays in the start-up of the In-Tank Precipitation (ITP) process, DWPF began processing sludge-only instead of the planned coupled sludge and Precipitate Hydrolysis Aqueous (PHA) feed. Because of the potential safety problems with the ITP process, CST is one of the four process options being considered as a replacement for ITP. CST is a non-elutable resin used to remove ${ }^{137} \mathrm{Cs}$ from the supernate fraction of SRS High Level Waste. The CST would be combined with the sludge in the SRAT (to replace the PHA that is currently part of DWPF's coupled flowsheet). Frit would be added to the SRAT product as in a typical DWPF SME cycle.

The salt disposition team requested ITS to assess the blending of CST resin with sludge in the DWPF Chemical Process Cell (CPC) on the maximum hydrogen generation rate produced during the DWPF melter feed preparation processes (Issue 21, HLE-TAR-98060). The melter feed produced during these experiments was subsequently used in a settling study (Issue 13, HLETAR-98060).

Testing was completed using a non-radioactive Tank 42 sludge simulant. A $1 / 10,000^{\text {th }}$ scale laboratory setup was used and the results then scaled for DWPF operations. HM levels (maximum expected concentrations) of noble metals and mercury were added to the sludge to maximize the hydrogen generation. The targeted CST concentration would result in 10 wt $\%$ CST in the glass. The CST was not loaded with noble metals.

This document details the testing performed to determine the maximum hydrogen generation expected with a coupled flowsheet of sludge, CSI, and frit.

\section{INTRODUCTION}

The objective of these scoping tests was to measure the rate of hydrogen generation in a series of experiments designed to duplicate the expected SRAT and SME processing conditions in laboratory scale vessels. The experiments were completed with a non-radioactive Tank 42 sludge simulant. The specific objectives of these tests were:

- Determine the maximum hydrogen generation rate during each SRAT and SME processing cycle.

- Determine any processing differences while completing SRAT/SME cycles with CST.

- Produce a melter feed suitable for subsequent settling studies. 


\section{DISCUSSION}

\section{Experimental}

\section{Method}

Four four-liter scale SRAT/SME processing runs were completed in the 772-T lab at TNX. Each of the runs consisted of a prototypic DWPF SRAT and SME cycle. The experimental setup was designed to volumetrically scale the DWPF vessels, flows, and feed-rates. For example, $2.0 \mathrm{~L}$ of sludge was used in each of the four runs. This is a scale factor of approximately $1 / 10,000^{\text {th }}$ of DWPF scale based on a 6000 -gallon DWPF sludge batch. Thus the 2 -gallon/minute acid addition rate was scaled down to $0.75 \mathrm{ml} / \mathrm{min}$. The experiments were controlled using a laboratory run plan (Appendix B). The Appendix B run plan also contains a sketch of the experimental setup and the scaled conditions used for these experiments.

The SRAT cycle includes all of the key DWPF processing steps (Table 1). The key activities in the SRAT cycle include the acidification of the sludge, reduction of various metals including manganese and mercury, and destruction of nitrite. Key data to be collected included hydrogen generation rate and foaming conditions.

Table 1 - Key Steps in the SRAT and SME Cycles

\begin{tabular}{|c|c|}
\hline SRAT Cycle Steps & SME Cycle Steps \\
\hline $\begin{array}{l}\text { 1. SRAT sludge preparation, sludge } \\
\text { analyrs batching calculations }\end{array}$ & $\begin{array}{l}\text { 1. First addition of a frit } 202 \text {-water- } \\
\text { formic acid slurry }\end{array}$ \\
\hline 2. Heat-up to $93^{\circ} \mathrm{C}$ & $\begin{array}{l}\text { 2. Boiling off water added with the } \\
\text { frit-water-sluny }\end{array}$ \\
\hline 3. Addition of nitric acid at $93^{\circ} \mathrm{C}$ & $\begin{array}{l}\text { 3. Second addition of a frit } 202 \text {-water- } \\
\text { formic acid slurry }\end{array}$ \\
\hline 4. Addition of formic acid at $93^{\circ} \mathrm{C}$ & $\begin{array}{l}\text { 4. Boiling off water to reach a target } \\
\text { solids loading of } 45 \mathrm{wt} \% \text { total } \\
\text { solids }\end{array}$ \\
\hline $\begin{array}{l}\text { 5. Addition of the first of two CST } \\
\text { slurry additions }\end{array}$ & 5. Cool-down and sample \\
\hline 6. Heat-up to boiling & \\
\hline $\begin{array}{l}\text { 7. Concentration down to } 6000 \\
\text { gallons }\end{array}$ & - \\
\hline $\begin{array}{l}\text { 8. Addition of the second CST slurry } \\
\text { addition }\end{array}$ & \\
\hline $\begin{array}{l}\text { 9. Heat-up to boiling and continue } \\
\text { boiling for a total of } 30 \text { hours }\end{array}$ & \\
\hline 10. Cooldown and sample. & \\
\hline
\end{tabular}

The SME cycle also includes all of the key DWPF processing steps (Table 1). Key data includes hydrogen generation rate and foaming likelihood. 
Three runs were completed with CST as requested by the scoping document (Appendix A). A fourth run was added to allow a direct comparison to the CST runs with the same sludge composition, laboratory setup, etc. The four runs are summarized in Table 2 . All the runs started with the same Tank 42 sludge simulant with HM levels of noble metals and mercury. The first experiment was a sludge-only experiment -- no CST added. The last three experiments were completed with CST in three different sizes: finely ground, mid-grind, and unground or asreceived.

Table 2 - Experimental Plan

\begin{tabular}{|c|c|c|c|c|}
\hline Run & Sludge & Noble Metals & CST & Acid \\
\hline Sludge-only & 42 & $\mathrm{HM}^{*}$ & None & $125 \%$ \\
\hline $\begin{array}{l}\text { Sludge plus fine } \\
\text { CST }\end{array}$ & 42 & HM & $\begin{array}{l}\text { Finely Ground CST treated } \\
\text { with caustic }\end{array}$ & $125 \%$ \\
\hline $\begin{array}{l}\text { Sludge plus mid- } \\
\text { grind CST }\end{array}$ & 42 & HM & $\begin{array}{l}\text { Mid-grind CST treated } \\
\text { with caustic }\end{array}$ & $125 \%$ \\
\hline $\begin{array}{l}\text { Sludge plus } \\
\text { unground CST }\end{array}$ & 42 & HM & $\begin{array}{l}\text { Unground CST treated } \\
\text { with caustic }\end{array}$ & $125 \%$ \\
\hline
\end{tabular}

In all of the runs, the nitric and formic acids were fed to the sludge-slurry at $93^{\circ} \mathrm{C}$. The SRAT contents were then heated to boiling and held there for 30 hours. The boilup rate chosen for these experiments was $33 \%$ higher than DWPF's boilup rate to limit the SRAT boiling time to 30 hours as opposed to 40 hours for scheduling reasons.

\section{Sludge Preparation}

The sludge simulant used in each of these runs contained approximately $20 \mathrm{wt} \%$ solids and was similar to the sludge that DWPF is expected to process. The sludge was prepared using a Tank 51 sludge-simulant (a non-radioactive simulant containing all the major sludge components except Uranium). The Tank 51 simulant was chosen because it is the sludge simulant closest to the Tank 42 composition. The Tank 51 simulant was doped with nickel, manganese, aluminum, and silica since these components are significantly higher in the Tank 42 sludge. In addition, the noble metals and mercury were added prior to each run. The trimmed sludge $1 \mathrm{~B}$ simulant was then analyzed for solids, elementals, total base (pH 5.5) and density. The composition of the sludge is summarized in Table 3 . Note that the nickel is higher than expected due to a double addition of nickel nitrate. Since this did not impact the objectives of the experiment, it was used as prepared with the concurrence of the customer.

The HM rhodium concentration is approximately 7 times higher than the expected Tank 42 nobje metal concentration. 
Table 3 - Tank 42 Sludge Simulant Composition

Pre Trim Chemical Addition (noble metals and mercury)

\begin{tabular}{|c|c|c|c|c|}
\hline & $\begin{array}{l}\text { Starting } \\
\text { Sludge }\end{array}$ & $\begin{array}{l}\text { Target } \\
\text { Sludge }\end{array}$ & $\begin{array}{l}\text { Predicted } \\
\text { Sludge }\end{array}$ & $\begin{array}{l}\text { Measured } \\
\text { Composition }\end{array}$ \\
\hline $\begin{array}{l}\text { Insoluble } \\
\text { Species }\end{array}$ & $\begin{array}{c}\text { Tank } 51 \text { Sludge } \\
\text { Simulant }\end{array}$ & $\begin{array}{l}\text { Tank } 42 \text { (bes } \\
\text { w/o U, Pu) }\end{array}$ & t estimate & \\
\hline & $\begin{array}{c}\text { actual w } \% \text { Dried } \\
\text { Solids }\end{array}$ & $\begin{array}{l}\text { wt\% Dried } \\
\text { Solids }\end{array}$ & $\begin{array}{c}\text { wt } \% \text { Dried } \\
\text { Solids }\end{array}$ & $\begin{array}{l}\text { wt\% Dried } \\
\text { Solids }\end{array}$ \\
\hline $\mathrm{Al}$ & 6.76 & 8.30 & 4824 & 6.74 \\
\hline $\mathrm{Ag}$ & 0.00 & 0.04 & 40044 & $t$ \\
\hline $\mathrm{Ca}$ & 2.67 & 2.49 & 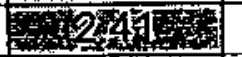 & 1.88 \\
\hline $\mathrm{Cd}$ & 0.00 & 0.11 & on 19 & \\
\hline $\mathrm{Cl}$ & 0.00 & 0.00 & BO 34 & \\
\hline $\mathrm{Cr}$ & 0.18 & 0.14 & ano 6 & \\
\hline $\mathrm{Cu}$ & 0.03 & 0.03 & 8,002 & 0.02 \\
\hline $\mathrm{F}$ & 0.01 & 0.01 & Popoy & \\
\hline $\mathrm{Fe}$ & 26.80 & 22.91 & $5=244$ & 21.35 \\
\hline $\mathrm{Hg}$ & 0.00 & 1.30 & 429 & $T^{\top}$ \\
\hline $\mathrm{K}$ & 0.14 & 0.10 & 62013 & 0.11 \\
\hline $\mathrm{Li}$ & 0.00 & 0.00 & 50400 & 0.00 \\
\hline $\mathrm{Mg}$ & 1.31 & 1.29 & (1) 8 & 1.00 \\
\hline $\mathrm{Mn}$ & 2.80 & 3.94 & 309014 V & 5.43 \\
\hline $\mathrm{Na}$ & 10.20 & 3.95 & 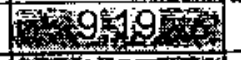 & 7.50 \\
\hline $\mathrm{Ni}$ & 0.24 & 0.39 & 06579 & 0.45 \\
\hline $\mathrm{P}$ & 0.00 & 0.93 & DOPSO , & \\
\hline $\mathrm{Pd}$ & 0.00 & $2.20 \mathrm{E}-03$ & $2215 \%$ & $\bar{t}$ \\
\hline$\overline{\mathrm{Pu}}$ & 0.00 & 0.00 & OOQO & \\
\hline $\mathrm{Rh}$ & 0.00 & $5.30 \mathrm{E}=03$ & 5265: & $t$ \\
\hline Ru & 0.00 & 0.02 & 100102 & $t$ \\
\hline $\mathrm{Se}$ & 0.00 & $0.00 \mathrm{E}+00$ & 10100,3 & $t$ \\
\hline $\mathrm{Si}$ & 0.81 & 1.43 & 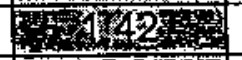 & 1.57 \\
\hline Te & 0.00 & 0.00 & :0100 & $t$ \\
\hline $\mathrm{Ti}$ & 0.04 & 0.02 & 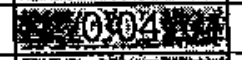 & 0.05 \\
\hline $\mathrm{Zn}$ & 0.17 & 0.08 & Hod 5 & 0.02 \\
\hline
\end{tabular}

\section{CST Preparation}

The CST (UOP IONSIV IE-911, Lot \#999096810004, 8/3/98) was prepared by grinding the CST, soaking the CST in caustic, drying the CST, and titrating the CST. Grinding was required to produce the appropriate particle size for the settling study. The CST was soaked in caustic to

${ }^{\dagger}$ Added with trim chemicals prior to each run. 
simulate the pre-treatment of the CST prior to using the CST in a column. The titration results were necessary to add sufficient acid to neutralize the caustic present in the CST. Approximately $1 \mathrm{ml}$ of formic acid (conservative for hydrogen generation) was added per batch to neutralize the caustic in the CST. The particle size of the CST used in each nun is summarized in Figure 1.

Figure 1 - CST Particle Size

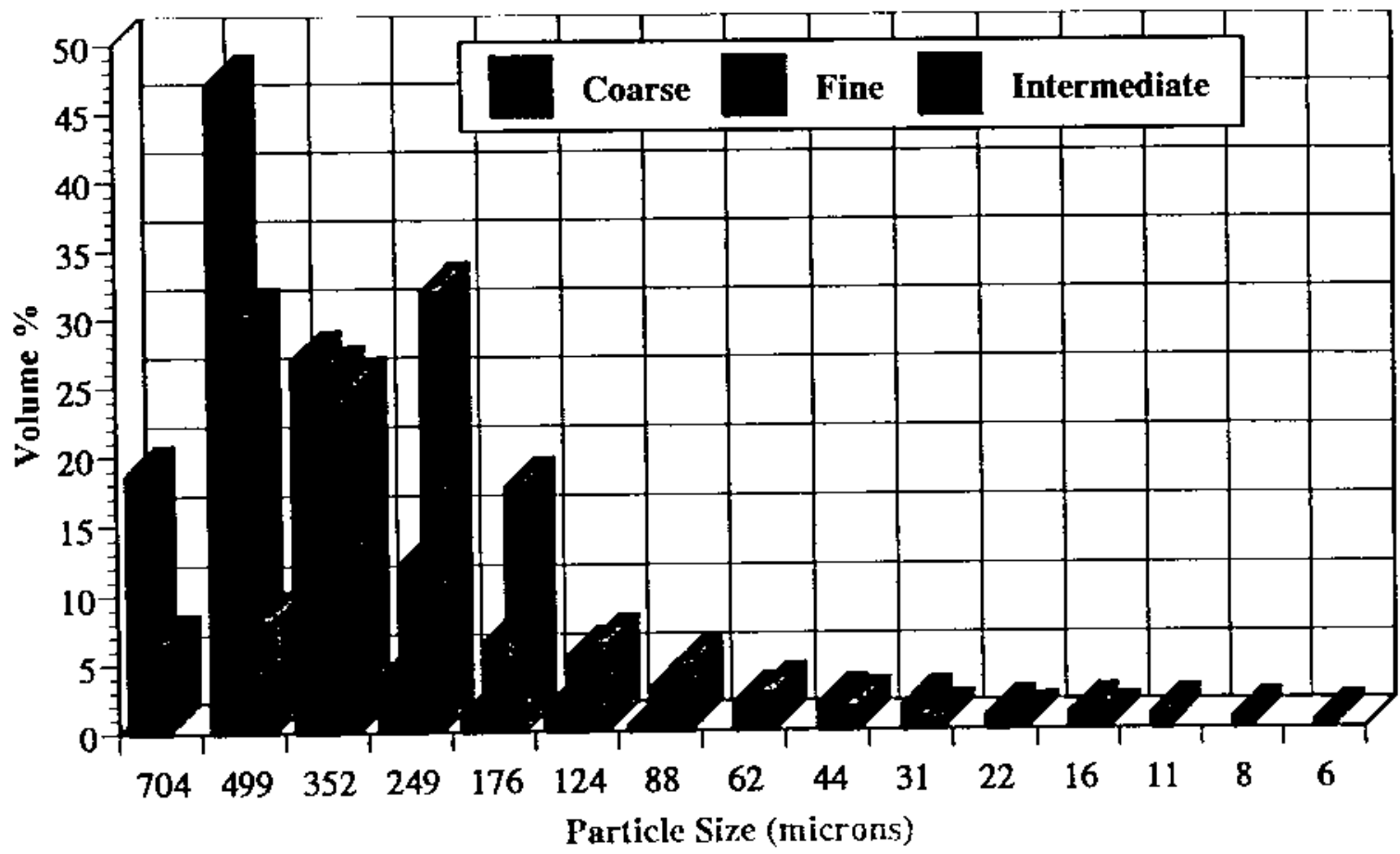

The as received or ground CST was placed in a $500 \mathrm{ml}$ flask and covered with about $250 \mathrm{ml}$ of 1 $\mathrm{M} \mathrm{NaOH}$ solution. This solution was gently stirred and allowed to contact the CST for a period of 37 to 43 hours.' The $\mathrm{NaOH}$ was then decanted and the CST was air dried under an infrared lamp $\left(58^{\circ} \mathrm{C}\right)$ in a shallow pan until dry. This material was then used in the study. This modified pretreatment method was approved by the customer.

\section{Acid Addition Strategy}

Concentrated formic acid (90-wt \%) and nitric acid (50-wt\%) were added to neutralize the sludge and complete the desired reduction and nitrite destruction reactions. Total acid additions were based on total acid to achieve stoichiometry and an acid mix to produce a more reducing redox than DWPF's current target (this is conservative since it adds more formic acid and less nitric acid). The redox target was $0.1-0.2 \mathrm{Fe}^{2+} / \Sigma \mathrm{Fe}$ redox ratio in the glass.

\section{CST Addition Strategy}

The CST was not metered into the SRAT (PHA is metered into the SRAT at boiling). It was added during non-boiling conditions. The CST was first added dry through a funnel to the kettle, followed by the water to simulate the addition of a $5.7 \mathrm{wt} \%$ CST-water slurry. 


\section{Antifoam Addition Strategy}

To prevent a loss of solids due to foaming, Dow Coming 544 antifoam was added per the DWPF antifoam strategy (100 ppm on a total solution basis, 1 part antifoam: 19 parts water every twelve hours) and as needed to control foaming in the experiments. The antifoam was not very effective in any of the tests and needed to be added as often as every two hours.

\section{Frit Addition Strategy}

Two equal additions of Frit 202, water, and formic acid were designed to duplicate the frit slurry that is transferred into the SME. Frit 202 was added because it is the frit used during coupled experiments. To be consistent, Frit 202 was also added to the sludge-only experiment. No water was added to simulate the addition of frit-decon water to the SME. The Frit 202 was added dry through a funnel to the kettle, followed by the addition of 90 -weight percent formic acid, and then water. The frit addition was calculated based on the addition of $74 \mathrm{wt} \%$ frit in glass for the sludge-only and $64 \mathrm{wt} \%$ frit in the coupled CST/Sludge experiments.

\section{Results}

\section{Offgas Composition}

The main purpose of the experiments was to measure the hydrogen generation rate. In order to calculate the hydrogen generation rate, the offgas flow and composition must be measured. It is difficult to measure the offgas flow accurately throughout the SRAT and SME cycle so an intemal helium standard was used to enable calculating the outlet flow ${ }^{\ddagger}$. The helium internal standard gas flow was metered in using a MKS mass flow controller. The MKS mass flow controller was calibrated before the run using an MKS GRBOR Mass Flow Controller Calibrator. In addition, a leak check was performed prior to each experiment to demonstrate that the laboratory system was leak free.

The offgas composition was monitored using a Gas Chromatograph. The MTI gas chromatographs were calibrated prior to each of the runs and a pre-run and post-run calibration check were performed each run to demonstrate that the measured composition of the calibration standard was within $10 \%$ of the certification concentration.

\section{SRAT Cycle Hydrogen Generation}

The maximum hydrogen generation was $0.40 \mathrm{lb} / \mathrm{hr}$ in the coarse CST SRAT cycle. This peak was at the onset of boiling which may be higher than DWPF would experience because the boilup rate was $33 \%$ higher than was prototypic. The maximum hydrogen generation was 0.34 $\mathrm{lb} / \mathrm{hr}$ if the onset peak was neglected. This is lower than the DWPF SRAT hydrogen limit of $0.65 \mathrm{lbs} / \mathrm{hr}$. Note that this hydrogen peak was at the onset of boiling after the CST addition. It is

A known rate of helium was added to the inlet air stream to the SRAT. The outlet gas flow was monitored for helium. The total outlet flow was calculated based on the dilution of the helium by air and other generated gases. 
normal to have a peak at the onset of boiling because hydrogen accumulates in the kettle during non-boiling conditions due to poor mass transfer. However, the higher boilup rate in these runs led to higher peaks at the initiation to boiling so the maximum hydrogen was also calculated by excluding one or two data points at the initiation to boiling. The large difference between the first week's runs and the second week's runs is due to the slightly higher formic acid concentration which led to faster nitrite destruction and more hydrogen in the second week's runs (see explanation in discussion of hydrogen generation). Figure 2 shows the hydrogen generation rate during each of the four SRAT cycles. Note that the hydrogen peak began earlier in the second week's runs because nitrite had not yet been destroyed at the same time in the cycle in the first week's runs. Also, the sharp drop in hydrogen concentration was due to the cooldown necessary to make the second CST addition. Table 4 shows the peak hydrogen generation rate in each of the four runs.

Table 4- SRAT Cycle Hydrogen Generation Summary

\begin{tabular}{|c|c|c|c|c|c|}
\hline & $\begin{array}{l}\text { Sludge Only } \\
\text { (No CST) }\end{array}$ & $\begin{array}{l}\text { Finely } \\
\text { ground } \\
\text { CST }\end{array}$ & $\begin{array}{l}\text { Mid-Grind } \\
\text { CST }\end{array}$ & $\begin{array}{c}\text { Coarse } \\
\text { CST (no } \\
\text { Grinding) }\end{array}$ & $\begin{array}{l}\text { DWPF } \\
\text { Limit }\end{array}$ \\
\hline 772-T Lab Room \# & 109 & 112 & 112 & 109 & \\
\hline Date & $8 / 12-13 / 98$ & $8 / 12-13 / 98$ & $8 / 19-20 / 98$ & $8 / 19-20 / 98$ & \\
\hline SRAT $\mathrm{H}_{2}$ Peak, vol \% & 0.194 & 0.255 & 0.533 & 0.54 & \\
\hline \multicolumn{6}{|c|}{ SRATHAPeakjab/hr r } \\
\hline SRAT $\mathrm{H}_{2}$ Peak, scc/min & 1.049 & 1.465 & 3.376 & 3.24 & \\
\hline \multicolumn{6}{|c|}{ 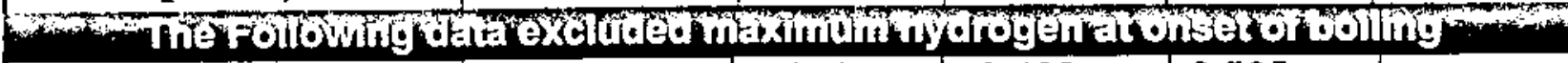 } \\
\hline SRAT $\mathrm{H}_{2}$ Peak, vol \% & 0.194 & 0.246 & 0.482 & 0.535 & \\
\hline SRAT $\mathrm{H}_{2}$ Peak, lb/hr & 0.125 & 0.168 & 0.328 & 0.343 & 0.65 \\
\hline SRAT $\mathrm{H}_{2}$ Peak, scc/min & 1.049 & 1.407 & 2.757 & 2.882 & \\
\hline
\end{tabular}


Figure 2 - SRAT Cycle Hydrogen Generation

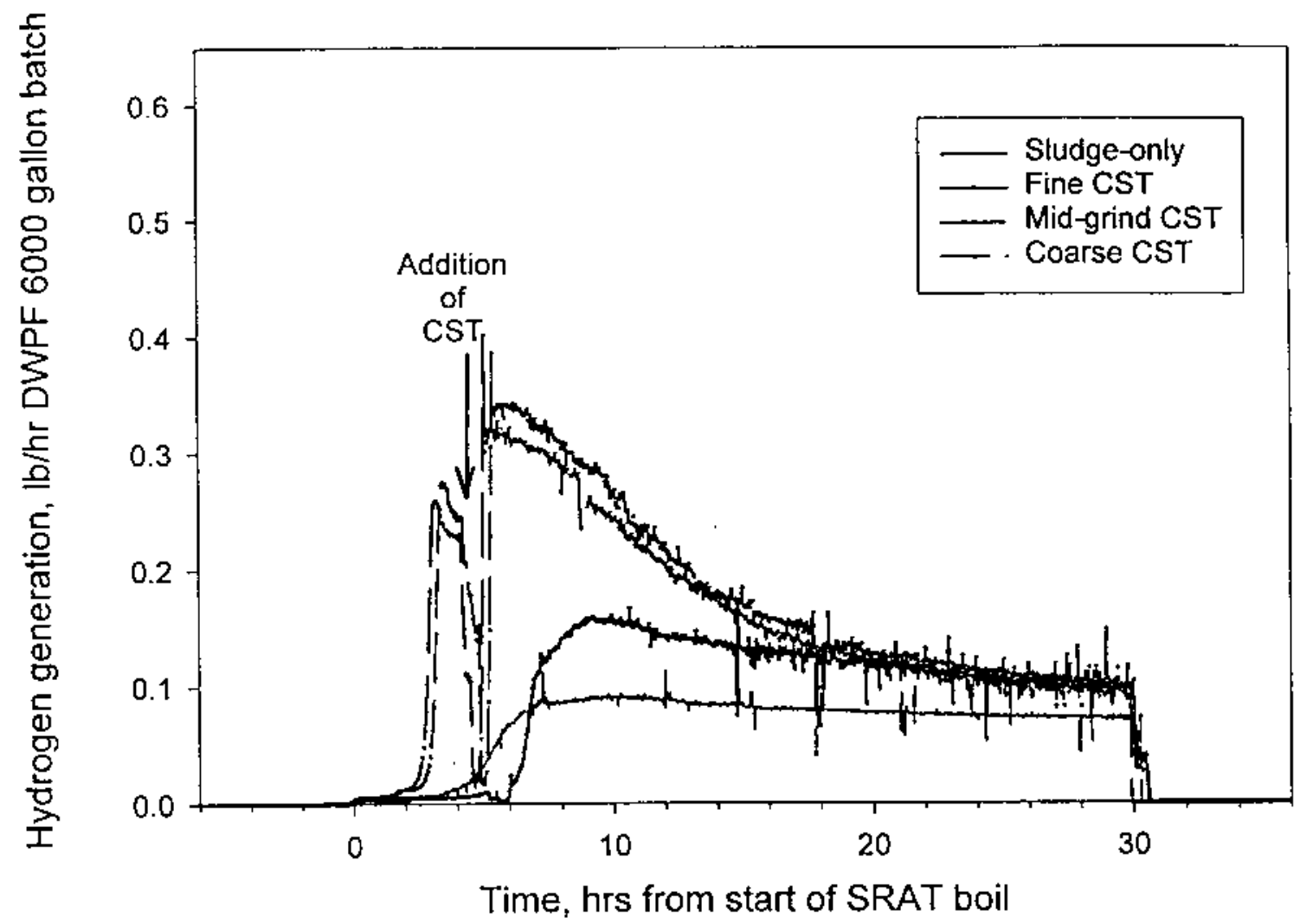

\section{SME Cycle Hydrogen Generation}

The maximum hydrogen generation was $0.217 \mathrm{lb} / \mathrm{hr}$ in the fine CST SME cycle. Note that this hydrogen generation rate is very close to the DWPF SME hydrogen limit of $0.23 \mathrm{lbs} / \mathrm{hr}$. This hydrogen peak was at the onset of boiling after the frit addition. As discussed in the SRAT section, it is nomal to have a peak at the onset of boiling because hydrogen accumulates in the kettle during non-boiling conditions due to poor mass transfer. However, the higher boilup rate in these runs led to higher peaks at the initiation to boiling so the maximum hydrogen was also calculated by excluding one or two data points at the initiation to boiling. The maximum hydrogen generation was $0.160 \mathrm{lb} / \mathrm{hr}$ neglecting the one or two data points at the onset of boiling in the coarse CST SME cycle. Figure 3 shows the hydrogen generation rate during each of the four SME cycles. Note that the hydrogen peaks are very similar for all four runs. The higher peaks might be due to sampling the offgas just as the peak occurred while the lower peaks may have missed the peak due to the fact that the GC samples every three minutes. Table 5 shows the peak hydrogen generation rate in each of the four runs. 
Figure 3 - SME Cycle Hydrogen Generation

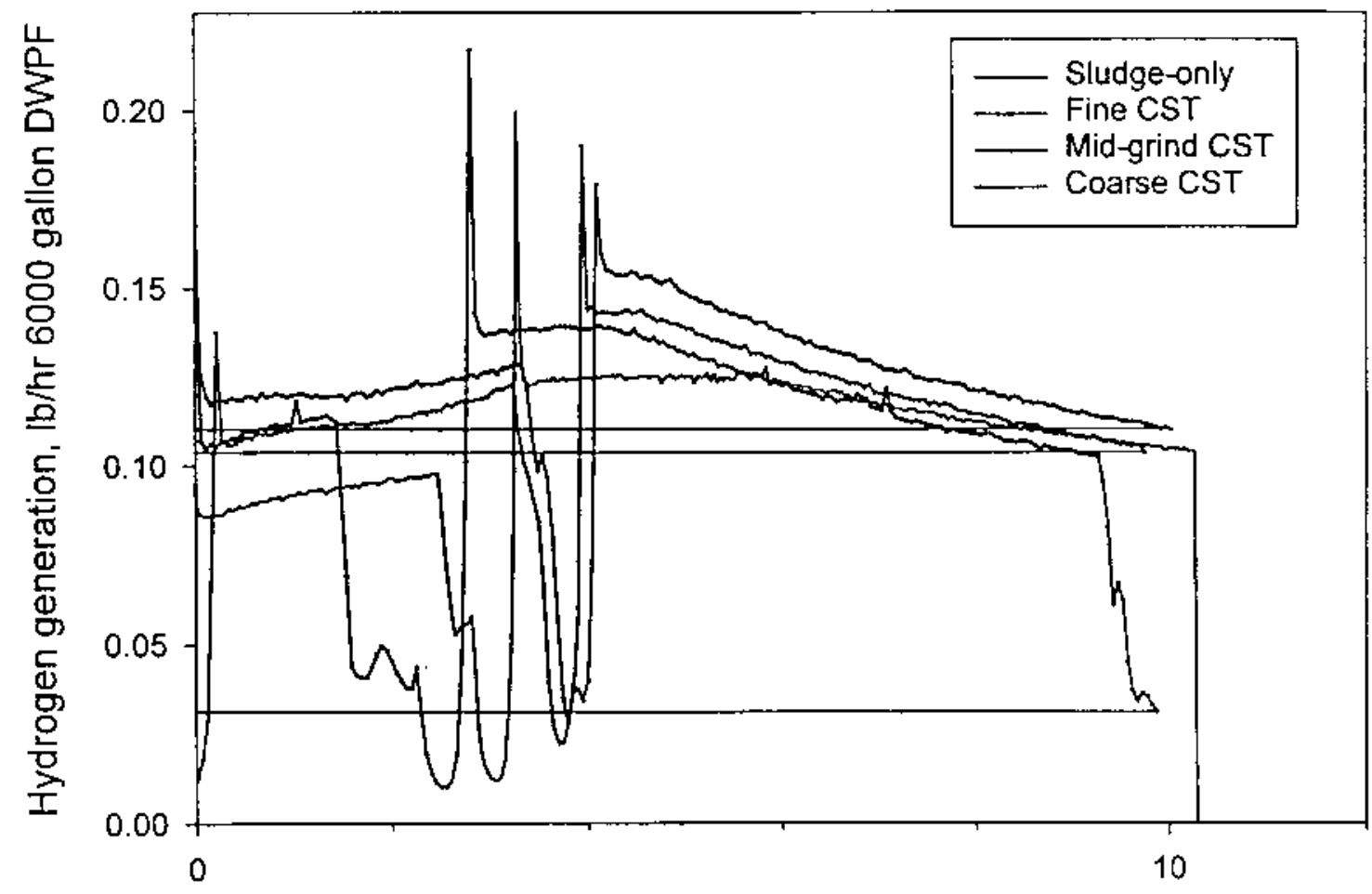

Time, hours from start of boiling in SME Cycle

Table 5- SME Cycle Hydrogen Generation Summary

\begin{tabular}{|c|c|c|c|c|c|}
\hline & $\begin{array}{c}\text { Sludge } \\
\text { Only No } \\
\text { CST }\end{array}$ & $\begin{array}{l}\text { Finely } \\
\text { ground } \\
\text { CST }\end{array}$ & $\begin{array}{l}\text { Mid-Grind } \\
\text { CST }\end{array}$ & $\begin{array}{l}\text { CST no } \\
\text { Grinding }\end{array}$ & $\begin{array}{l}\text { DWPF } \\
\text { Limit }\end{array}$ \\
\hline 772-T Lab Room \# & 109 & 112 & 112 & 109 & \\
\hline Date & $8 / 12-13 / 98$ & $8 / 12-13 / 98$ & $8 / 19-20 / 98$ & $8 / 19-20 / 98$ & \\
\hline SME $\mathrm{H}_{2}$ Peak, vol \% & 0.773 & 0.538 & 0.789 & 0.727 & \\
\hline SMEH2PeakjG/hit & (3) & 0217 & 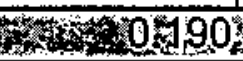 & 0.79 & 0.228 \\
\hline SME H ${ }_{2}$ Peak, scc/min & 1.680 & 1.823 & 1.595 & 1.506 & \\
\hline \multicolumn{6}{|c|}{ The Following data excluded maximum hydrogen at onset of boiling } \\
\hline SME H $\mathrm{H}_{2}$ Peak, vol \% & 0.542 & 0.115 & 0.654 & 0.663 & \\
\hline SME $\mathrm{H}_{2}$ Peak, lb/hr & 0.128 & 0.140 & 0.145 & 0.160 & 0.228 \\
\hline SME $\mathrm{H}_{2}$ Peak, scc/min & 1.074 & 1.172 & 1.217 & 1.340 & \\
\hline
\end{tabular}




\section{Discussion of Hydrogen Generation}

The hydrogen generation was approximately two times higher in the second set of runs (intermediate CST and coarse CST) than in the first set of runs (fine CST and sludge-only). This could be caused by (1) differences in the CST due to caustic preparation or particle size, (2) higher rhodium concentration in the second set of runs versus the first set, and (3) higher acid addition in the second set of runs versus the first set. A discussion of these possible causes follows:

1. The CST prepared to be the smallest particle size was actually larger than the mid-grind CST. Therefore, the second week was completed with the largest and smallest CST particle size. Since these experiments agreed so well, it is concluded that differences in the CST due to caustic preparation or particle size had nothing to do with the differences in hydrogen generation.

2. SRAT product samples were analyzed for noble metals to determine whether there was a significant difference in the noble metal concentration in week \#I versus week \#2. Note the four rhodium analyses were within $20 \%$ of each other which demonstrates that the same quantity of rhodium was added to each batch. A sodium peroxide fusion was performed on these samples prior to analysis by ICP-MS. The concentrations (Table 6) are reported in units of microgram/gram.

3. A new bottle of formic acid was used in week $\# 2$ since the formic acid bottle did not have enough formic acid to complete the experiments. The final $\mathrm{pH}$ after both nitric and formic acids were added was 4.45 in the first set of runs and 4.15 in the second set of runs. This is a significant $\mathrm{pH}$ difference -- all runs would be expected to end this phase of the run with approximately the same $\mathrm{pH}$. The SRAT product samples were analyzed for total formate to determine whether there was a significant difference in the formate concentration in week \#1 versus week \#2. The SRAT product samples from the week \#2 samples were significantly lower in formate (opposite of what would be expected assuming a larger formic acid addition), due to the loss of formic acid due to hydrogen generation. No samples of the old or new bottle of formic acid were available for analysis. Analysis to distinguish a molarity difference between two bottles of $90 \mathrm{wt} \%$ formic acid using the titration procedure probably would have been unsuccessful.

The likely reason for the difference is that more formic acid was added in the second set of runs. A different bottle of $90 \mathrm{wt} \%$ formic acid was used which was probably slightly higher in molarity. The final $\mathrm{pH}$ after both nitric and formic acids were added was 4.45 in the first set of runs and 4.15 in the second set of runs. This small change in $\mathrm{pH}$ led to faster nitrite destruction, earlier generation of hydrogen, and higher generation rate of hydrogen. Consequently, a direct comparison can be made only between the two runs completed in the same week.

In a previous Sludge-only SRAT cycle with Tank 42 sludge simulant, the hydrogen generation rate was $0.104 \mathrm{lb} / \mathrm{hr}^{2}$. The run was lower in solids (hence lower in noble metals). Correcting for the lower solids in the original SRAT cycle ( $17 \mathrm{wt} \%$ versus $20 \mathrm{wt} \%)$, the predicted hydrogen generation at $20 \mathrm{wt} \%$ solids is $0.122 \mathrm{lb} / \mathrm{hr}(0.104 \mathrm{lb} / \mathrm{hr} * 20 \mathrm{wt} \% / 17 \mathrm{wt} \%)$. 
Table 6 - ICP Analysis of SRAT Product Samples for Noble Metais

\begin{tabular}{|l|l|r|r|r|}
\hline Run & \multicolumn{1}{l}{ LMMS \# } & \multicolumn{1}{c|}{ Ruthenium } & Rhodium & Palladium \\
\hline Sludge-only & 3000114490 & 1530 & 191 & 600 \\
\hline Fine CST & 3000114491 & 1279 & 169 & 618 \\
\hline Mid-grind CST & 3000114492 & 1388 & 199 & 281 \\
\hline Coarse CST & 3000114493 & 1295 & 190 & 431 \\
\hline
\end{tabular}

The following discussion is based on the hydrogen generation rates where one or two data points were excluded at the onset of boiling. It appears that the hydrogen generation was higher in the CST runs than the sludge-only run based on the difference between the two runs. It is also apparent that less total acid could be added to destroy nitrite since the hydrogen peak occurs very early in the SRAT cycie. Thus, the hydrogen generation rates are conservative compared to the optimum process.

\section{Foaming}

The experiments with CST produced more foam than the sludge-only experiment. There are two contributing factors, solids concentration and boilup rate. First, a high solids concentration leads to high foam stability. Experiments by researchers at the Illinois Institute of Technology have demonstrated that the foam stability is at a maximum at $25-35$ weight percent solids. These experiments were conducted near this peak. These runs began with 20 weight percent solids, then the addition of CST brought the solids concentration up to approximately 33 weight percent solids (sludge-only was $25 \mathrm{wt} \%$ solids). Second, these experiments were completed at a boilup rate one-third higher than previous experiments to reduce the SRAT boiling time ( $4 \mathrm{~g} / \mathrm{min}$ boilup rate leads to a 30 hour boiling time versus scaled boilup of $3 \mathrm{~g} / \mathrm{min}$ would have led to a 40 hour boiling time) due to technician scheduling constraints. The boiling flux at $4 \mathrm{~g} / \mathrm{min}$ is approximately $9 \mathrm{lb} / \mathrm{hr} / \mathrm{ft}^{2}$, far lower than the DWPF flux of $50 \mathrm{lb} / \mathrm{hr} / \mathrm{ft}^{2}$. But since the vapor space in the kettle (approximately five inches) is much smaller than in DWPF it is easy for the foam layer to grow out of the kettle and cause a loss of solids to the condensate.

The foam was greatest in the experiment with the coarse CST. These experiments had approximately five inches of stable foam throughout the SRAT cycle. The foam layer was much lower during the SME cycles -- no more than one inch of foam. The SRAT cycle foam layer was approximately one inch in the experiment with intermediate grind CST and fine CST. However, it should be noted that the experiment with fine CST had as much as five inches of foam at one time based on the solids noted in the vapor space of the kettle. The foam layer was even smaller in the sludge-only experiment, less than 1 inch. However, antifoam was not added to the sludgeonly experiment prior to initiation of the boiling phase following the acid addition resulting in some solids foaming over into the mercury water wash tank. The condensate and solids were returned to the kettle, antifoam was added and boiling resumed with no further foaming problems. 


\section{FUTURE WORK}

The scoping experiments were designed primarily to measure hydrogen generation in identical experiments. Variability studies and other problems noted in these experiments should be investigated if this flowsheet is recommended for development at SRS. Future work should consider completing experiments to test the following items:

1. Pre-treat the CST by loading the CST with a salt solution simulant to produce loaded CST resin. This would require pumping a salt solution containing noble metals once through the CST. The CST may adsorb the noble metals leading to higher hydrogen generation than would be measured with a fresh resin.

2. Develop a CST flowsheet that minimizes the formic acid addition required to destroy nitrite in the SRAT Cycle.

3. Develop a better antifoam for boiling operations

4. Develop a flowsheet with an acid mix to produce a melter feed with an optimum redox.

5. Continue studying the hydrogen generation. Develop a relationship to predict the generation rate of hydrogen during processing with CST.

\section{ACKNOWLEDGMENTS}

Thanks to Roy Jacobs and Joe Carter for providing quick answers to our questions and direction as needed.

Thanks to Frances Williams, Sammie King, John Duvall, Mary Johnson, Vickie Williams for doing an excellent job of preparing for and performing the planned experiments. Their ability to work well as a team is very much appreciated. We appreciate the long hours and especially the long nights you worked to accomplish these experiments. And you accomplished almost all of it while ITS was one technician short.

We especially appreciated the excellent technical support (as always) we got from Gene Daniel, Paul Monson, and Russ Eibling. We tried a lot of new things (new GCs, new stirrers, new temperature controllers, new temperature baths, new mass flow calibrator) which helped us to improve the quality of our experiments.

Thanks to William Ryan for ordering everything we needed and quickly sending it back when it failed to work. Thanks also to Nick Odom for setting up the mass flow calibrator, calibrating so many flowmeters, and affixing his new seal of approval on the flowmeters.

We appreciated the quick turnaround and accurate analyses that were reported by the ADS lab. ADS's help was essential in providing accurate, timely results to calculate the batching for the experiments. ADS also provided the noble metal analyses (Laura Tovo) and the anion results (Robert Ray) necessary for understanding the hydrogen differences from week \#1 to week \#2. Thanks to David Best and Eric Frickey for the melter feed elemental results. 
Westinghouse Savannah River Company

Savannah River Technology Center

WSRC-TR-98-00297, Revision 0

\section{REFERENCES:}

1 TAR, HLE-TAR-98060.

${ }^{2}$ D. P. Lambert, C. S. Boley, Tank 42 Sludge-only Process Development for the Defense Waste Processing Facility (DWPF) (U), WRC-RP-98-0149, Revision 1, September 2, 1998. 


\section{APPENDIX A - RUN PLAN}

ITS has been requested to assess the impact of blending CST resin with sludge in the DWPF SRAT on hydrogen generation during DWPF melter feed prep experiments (HLE-TAR-98060, 7/20/98). ITS responded by issuing a document summarizing the scope of work and task assignment (SRT-PTD-98-032) for completing this task prior to September 21, 1998. This experimental work will be controlled using the Laboratory Scale Chemical Process Cell Simulations (Manual L27, Procedure 2.02) and this run plan. The run plan includes many of the experimental details, the instructions for performing the sludge preparation, the scaling necessary for determining the operating conditions such as feed rates, purge rates, and the steps in completing the SRAT and SME cycles. This document also summarizes the decisions made to complete these experiments. This document has been revised now that the sludge and other analyses are complete.

1) Use Tank 42 sludge simulant prepared from the Optima prepared Tank 51 simulant. Note that this Tank simulant was prepared for other Tank 42 work but because of the high priority of this task, the simulant will be used for this study instead. The following trimming of the sludge is summarized in Table 1.

a) The Tank 42 sludge simulant was prepared at approximately $20 \mathrm{wt} \%$ solids, the expected composition of DWPF macrobatch 2.

b) HM levels of noble metals and mercury will be added to each sludge batch (Table 2). This will require approximately 30 hours of boiling in the SRAT to steam strip mercury and meet DWPF constraint of 0.45 wt \% mercury.

Table 7 - Preparation Of Tank 42 Sludge For All Experiments (Trim Chemicals Missing)

\begin{tabular}{|c|c|c|}
\hline Component & Amount, $\mathrm{g}$ & Comment \\
\hline Tank 51 sludge simulant & $12,210.14$ & 19.95 wt \% solids (too high in solids) \\
\hline Tank 51 supernate & $1,657.30$ & \\
\hline $\mathrm{Al}_{2} \mathrm{O}_{3}$ & 115.99 & \\
\hline $\mathrm{Ni}\left(\mathrm{NO}_{3}\right)_{2} \cdot 6 \mathrm{H}_{2} \mathrm{O}$ & 49.54 & $\begin{array}{l}\text { Nickel was added twice } \\
\text { inadvertently }{ }^{\S} \text {. The final sludge is } \\
\text { predicted to be } 0.57 \% \mathrm{Ni} \text { versus } \\
\text { the target of } 0.39 \% \text {. }\end{array}$ \\
\hline $\mathrm{SiO}_{2}$ & 41.93 & \\
\hline $\mathrm{MnO}_{2} \times \mathrm{H}_{2} \mathrm{O}$ & 62.66 & Added $230.40 \mathrm{~g} @ 27.2$ wt \% solids \\
\hline $\mathrm{MnO}_{2} \cdot \times \mathrm{H}_{2} \mathrm{O}$ & 168.4 & Added621.4g@27.1wt \% solids \\
\hline Water & 200.00 & \\
\hline$\overline{\mathrm{Al}_{2} \mathrm{O}_{3}}$ & 0.94 & \\
\hline $\mathrm{Na}_{2} \mathrm{C}_{2} \mathrm{O}_{4}$ & 4.87 & \\
\hline $\mathrm{NaF}$ & 0.66 & \\
\hline $\mathrm{NaOH}$ & 7.05 & \\
\hline $\mathrm{NaCl}$ & 0.82 & \\
\hline
\end{tabular}

${ }^{5}$ The simulant was approved for use by Roy Jacobs in spite of the extra nickel. 
Westinghouse Savannah River Company

Savannah River Technology Center

WSRC-TR-98-00297, Revision 0

Table 8 - Trim Chemical Addition For Each Batch

\begin{tabular}{|c|c|c|c|c|c|}
\hline & Mass, grams & $\begin{array}{c}\text { Actual } \\
\text { Addition }\end{array}$ & $W t \%$ & \multicolumn{2}{|c|}{\begin{tabular}{|ll} 
Solids mass, $\mathrm{g}$ & $\begin{array}{l}\text { Solids added, } \\
\mathrm{g}\end{array}$
\end{tabular}} \\
\hline Sludge & $2,270.0$ & & $19.3 \%$ & 438.11 & 19.388 \\
\hline Trim Chemicàl & Mass, grams & $\begin{array}{l}\text { Actual } \\
\text { Addition }\end{array}$ & $\begin{array}{l}\text { Water } \\
\text { added }\end{array}$ & $\begin{array}{c}\text { mass fraction } \\
\text { element in } \\
\text { solution }\end{array}$ & $\begin{array}{l}\text { mass percent } \\
\text { element in } \\
\text { solution }\end{array}$ \\
\hline $\mathrm{RuCl} 3$ & 2.3785 & & & $4 \times 042,24$ & Dy \\
\hline $\mathrm{Rh}(\mathrm{NO} 3) 3 \cdot 2 \mathrm{H} 2 \mathrm{O}$ & 2.5968 & & & 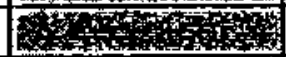 & S \\
\hline $\mathrm{Pd}(\mathrm{NO} 3) 2 \cdot \mathrm{H} 2 \mathrm{O}$ & 2.3669 & & & 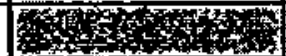 & $+128 x^{0}$ \\
\hline $\mathrm{AgNO} 3$ & 0.1009 & & & w $046350 \%$ & 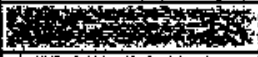 \\
\hline HgO (Yellow) & 16.1189 & & & 210026180 & 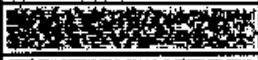 \\
\hline $\mathrm{SeO} 2$ & 0.0257 & & & 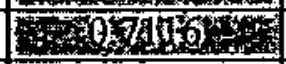 & DN \\
\hline $\mathrm{TeO} 2$ & 0.2747 & & & 602995 & WSt \\
\hline
\end{tabular}

\begin{tabular}{|c|c|}
\hline Element & Concentration \\
\hline 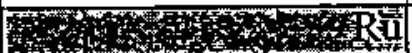 & $0.217 \% \mathrm{H} \%$ \\
\hline 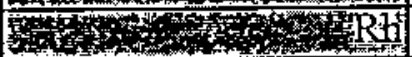 & $0.028 \% \bar{M} / \%$ \\
\hline 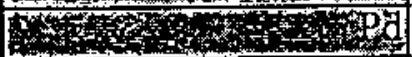 & $0.079 \%$ \\
\hline ( & $0.014 \% \% \% \%$ \\
\hline 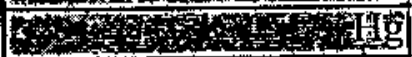 & $3.263 \% 0 \%=0$ \\
\hline $564+4,4 \%$ \& & $0.004 \%$ x $6 \%$ \% \% \\
\hline 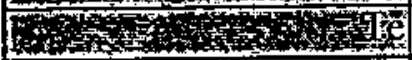 & 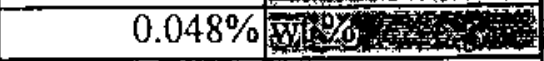 \\
\hline 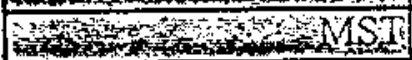 & $0.000 \%$ Wh \\
\hline
\end{tabular}

2) Three different CST resin sizes will be used in the three experiments (the only planned variable). The smaller resin sizes will be produced by crushing or grinding the CST.

3) The CST will be prepared by pumping $1 \mathrm{M} \mathrm{NaOH}$ through a CST column to pre-treat the resin.

4) The CST resin will be added to water and titrated to determine the amount of acid necessary to neutralize the CST resin.

5) The CST resin will be added dry to the kettle after acid addition. To simulate the slurry that would be added, water will also be added to simulate the water present in the slurry (based on a $5.7 \mathrm{wt} \%$ slurry). Two additions of the CST resin slurry will be made with a dewatering phase between them to make room in the kettle for all of the solution.

6) The batching of the materials is designed to produce a glass containing $10 \mathrm{wt} \% \mathrm{CST}, 26 \mathrm{wt}$ $\%$ calcined sludge solids, and $64 \mathrm{wt} \%$ frit 200 . The batching calculations are summarized in Table 3.

7) Calculated acid addition rates, boilup rates, purge rates, antifoam addition, etc. were based on scaling from DWPF settings. Table 4 summarizes the results from the scaling calculations.

8) Add $125 \%$ of stoichiometric acid to duplicate Tank 42 experiment $3 \mathrm{~V}$ with a redox target of $0.2 \mathrm{Fe}^{+2} / \Sigma \mathrm{Fe}$.

9) The addition of CST adds no safety risks to the experiment as it is inert, similar to frit. 
10) A review, as required by the Conduct of Research and Development has been completed and was attached as appendix A of revision 0 of this report.

11) The experiments are planned to be completed the weeks of August 14 and August 21, 1998. The report is planned to be issued prior to September 21, 1998.

Table 9 - Batching Calculation for Coupled Sludge/CST Experiment

\begin{tabular}{|c|c|c|}
\hline \multicolumn{3}{|l|}{ Batching Summary } \\
\hline 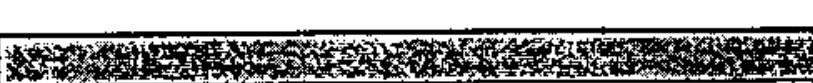 & 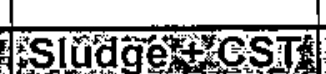 & Slúdgeonly \\
\hline Sludge Mass & $2,270 \mathrm{~g}$ & $2,270 \mathrm{~g}$ \\
\hline Nitric Acid Volume, $\mathrm{ml}$ & $50.271 \mathrm{ml}$ & $50.271 \mathrm{ml}$ \\
\hline Formic Acid Volume, $\mathrm{ml}$ & $110.399 \mathrm{ml}$ & $109.386 \mathrm{ml}$ \\
\hline CST Addition \#1, $\mathrm{g}$ & $68.54 \mathrm{~g}$ & $0.00 \mathrm{~g}$ \\
\hline CST Water Addition \#1, g & $1133.86 \mathrm{~g}$ & $0.00 \mathrm{~g}$ \\
\hline CST Addition \#2, $\mathrm{g}$ & $68.54 \mathrm{~g}$ & $0.00 \mathrm{~g}$ \\
\hline CST Water Addition \#2, $\mathrm{g}$ & $1133.86 \mathrm{~g}$ & $0.00 \mathrm{~g}$ \\
\hline SRAT Product Sample, ml & 125 & 125 \\
\hline Frit 202 Addition $\# 1, \mathrm{~g}$ & $411.22 \mathrm{~g}$ & $475.49 \mathrm{~g}$ \\
\hline SME Water Addition \#1, g & $756.15 \mathrm{~g}$ & $874.33 \mathrm{~g}$ \\
\hline SME $90 \mathrm{wt} \%$ Formic Acid Addition \#1, g & $7.54 \mathrm{~g}$ & $8.72 \mathrm{~g}$ \\
\hline Frit 202 Addition \#2, $\mathrm{g}$ & $411.22 \mathrm{~g}$ & $475.49 \mathrm{~g}$ \\
\hline SME Water Addition \#2, $\mathbf{g}$ & $756.15 \mathrm{~g}$ & $874.33 \mathrm{~g}$ \\
\hline SME 90 vt\% Formic Acid Addition $\# 2, \mathrm{~g}$ & $7.54 \mathrm{~g}$ & $8.72 \mathrm{~g}$ \\
\hline SRAT Air Purge, scc/min & 529.5 & 529.5 \\
\hline SRAT Helium purge, scc/min & 2.66 & 2.66 \\
\hline SME Air Purge, scc/min & 185.9 & 185.9 \\
\hline SME Helium purge, scc/min & 0.93 & 0.93 \\
\hline
\end{tabular}


Westinghouse Savannah River Company

Savannah River Technology Center

WSRC-TR-98-00297, Revision 0

Table 10- Scaling Calculation For Coupled Sludge/CST Experiment

\begin{tabular}{|c|c|c|c|}
\hline \multirow{2}{*}{ Scale factor } & DWPF & TNX 4L & Time \\
\hline & & 10,004 & \\
\hline Sludge & 6,000 gal & $2000 \mathrm{ml}$ & \\
\hline Sludge Density & 1.135 & 1.135 & \\
\hline Sludge Mass & $25777 \mathrm{~kg}$ & $2270.0 \mathrm{~g}$ & \\
\hline SRAT Water & $0 \mathrm{gal}$ & & \\
\hline SRAT purge & $188 \mathrm{scfm}$ & $532.1 \mathrm{scc} / \mathrm{min}$ & \\
\hline SME purge & $66 \mathrm{scfm}$ & $186.8 \mathrm{scc} / \mathrm{min}$ & \\
\hline Äntifoam & $5.68 \mathrm{lbs}$ & $0.23 \mathrm{~g}$ & \\
\hline Antifoam Solution & $113.66 \mathrm{lbs}$ & $4.54 \mathrm{~g}$ & \\
\hline CST Volume & $6,189 \mathrm{gal}$ & $206 \overline{3} .0 \mathrm{ml}$ & \\
\hline CST Mass & $24258 \mathrm{~kg}$ & $2,136.2 \mathrm{~g}$ & \\
\hline CST Feedrate & $100 \mathrm{gpm}$ & $37.8 \mathrm{ml} / \mathrm{min}$ & $1.0 \mathrm{hrs}$ \\
\hline nitric acid feedrate & $2 \mathrm{gpm}$ & $0.753 \mathrm{ml} / \mathrm{min}$ & $1.1 \mathrm{hrs}$ \\
\hline formic acid feedrate & $2 \mathrm{gpm}$ & $0.757 \mathrm{ml} / \mathrm{min}$ & $2.4 \mathrm{hrs}$ \\
\hline boilup rate & $5,000 \mathrm{lb} / \mathrm{hr}$ & $3.78 \mathrm{~g} / \mathrm{min}$ & \\
\hline Formic Molarity & $23.55 \mathrm{M}$ & $23.55 \mathrm{M}$ & \\
\hline Nitric Molarity & $10.35 \mathrm{M}$ & $10.40 \mathrm{M}$ & \\
\hline Formic Volume & 289.1 gall & $109.39 \mathrm{ml}$ & \\
\hline Formic híass & & $131.75 \mathrm{~g}$ & \\
\hline Nitric Volume & $133.5 \mathrm{gal}$ & $50.27 \mathrm{ml}$ & \\
\hline Nitric Mass & & $65.88 \mathrm{~g}$ & \\
\hline formic feed time & $144.5 \mathrm{~min}$ & $144.5 \mathrm{~min}$ & \\
\hline Nitric feed time & $66.8 \mathrm{~min}$ & $66.8 \mathrm{~min}$ & \\
\hline
\end{tabular}




\section{PREREQUISITES}

1. Signed TAR requesting work.

2. Issued Testing scope and task assignment.

3. Calibrate GC. Calibrate for nitrogen, oxygen, $\mathrm{N}_{2} \mathrm{O}$, hydrogen, and carbon dioxide.

4. Prepare sufficient $90 \%$ formic acid and $50 \%$ nitric acid.

5. Prepare sufficient antifoam solution or make sure sufficient solution is available.

6. Analyze sludge for density, total base (pH 5.5), nitrate, manganese, nitrite, density, solids.

7. Analyze MST for total solids.

8. Calculate batching for experiment based on planned conditions (Table 1).

9. Calculate scaling for experiment based on DWPF parameters (Table 2).

10. Calculate redox for experiment based on DWPF parameters (Table 3).

11. Complete water run.

12. Grind CST as directed by Roy Jacobs.

13. Prepare CST as directed by Roy Jacobs.

14. Setup experimental rig per sketch below.

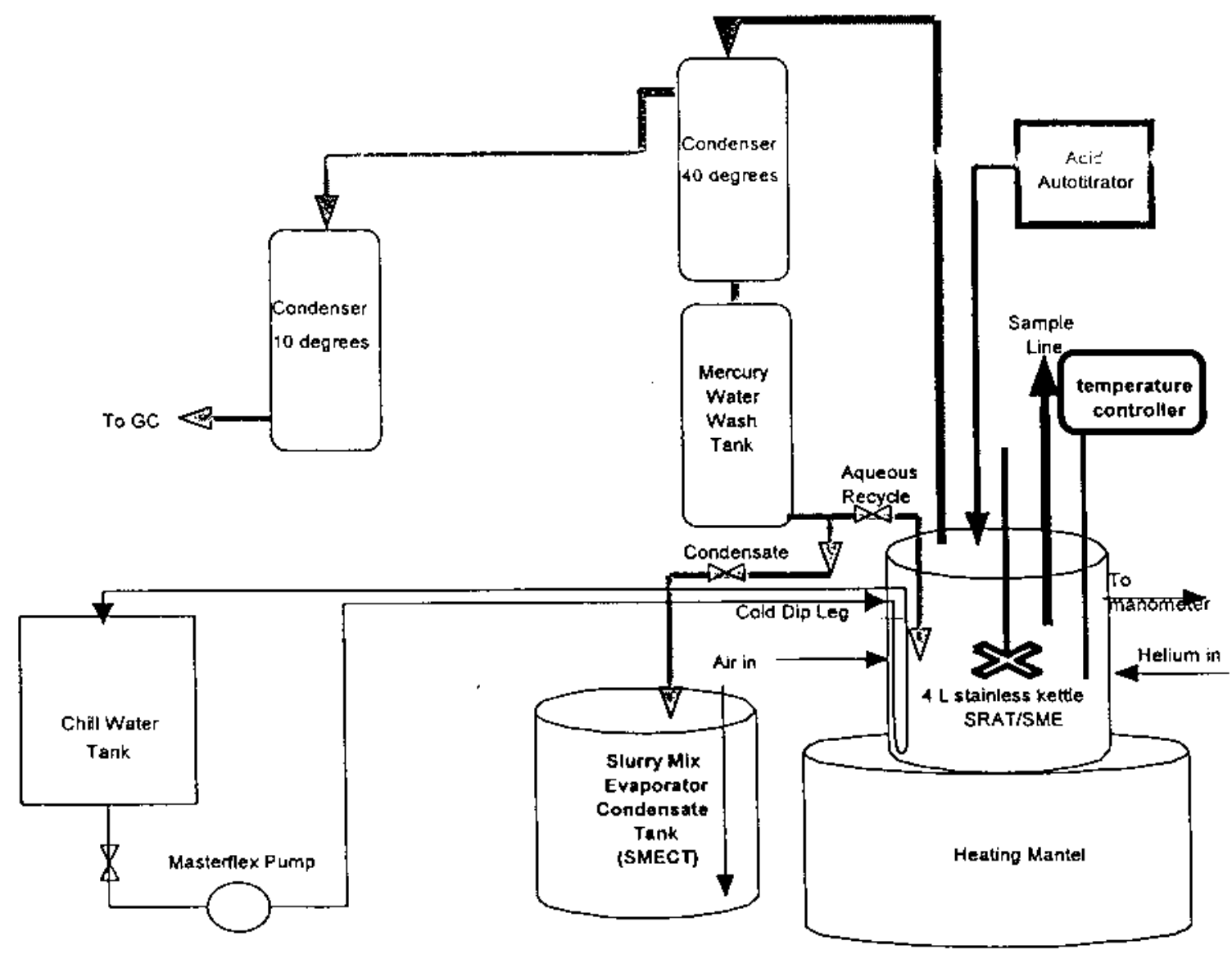




\section{PREPARATION FOR SRAT CYCLE}

Note: Do not insulate kettle until acid addition is complete

1. Add sludge (from the run sheet, Table 4) to kettle.

2. Add trim chemicals (from the run sheet, Table 4) directly to the kettle.

3. Transfer 100 grams of wash water to the kettle (to rinse all containers used for adding siudge, noble metals, mercury, etc.).

4. Calibrate $\mathrm{pH}$ probe with $\mathrm{pH} 4$ and 10 buffer. Record measured $\mathrm{pH}$ of $\mathrm{pH} 7$ buffer

5. Install $\mathrm{pH}$ probe in kettle. Record initial $\mathrm{pH}$ of sludge

6. Turn on the air purge to kettle at $\mathbf{1 0 0} \mathrm{sccm}$. Connect the outlet flowmeter to perform the leak check. The outlet flow should be $\mathbf{9 0 - 1 1 0 ~ s c c m . ~ I f ~ i t ~ i s ~ n o t , ~ t i g h t e n ~ a l l ~ c o n n e c t i o n s ~}$ until the system is leak tight. Write down the leak check in the log book.

7. Disconnect outlet fiowmeter.

8. Turn on kettle agitator. Setpoint $=150 \mathrm{rpm}$

9. Tum on cooling water to SRAT condenser. Setpoint $=40^{\circ} \mathrm{C}$.

10. Tum on cooling water to Chilled (FAVC) condenser. Setpoint $=5^{\circ} \mathrm{C}$.

11. Make sure the GC computer has enough memory space for the run (at least $40 \mathrm{Mbyte}$ ).

12. Set the GC computer time equal to the clock time. Record the time in the log book.

13. Install the calibration gas cylinder to the $\mathrm{GC}$ and let the $\mathrm{GC}$ run five times. If at the end of five runs the $\mathrm{GC}$ reading is within $10 \%$ of the gas composition in the cylinder, print the calibration check results and write down "pre-cal check and run number" on the printout. Otherwise, select "Calibration" "Level l" "OK" to calibrate the GC five times. At the end of five runs the GC reading should be within $10 \%$ of the gas composition in the cylinder. If it is not, contact the engineer. Print the calibration check results and write down "pre-cal check and run number" on the printout.

14. Start the GC for this run beginning with baseline reading for a few minutes. Write down the GC time, filename etc. in the logbook. Record the baseline data on the data sheet. 


\section{SRAT CYCLE}

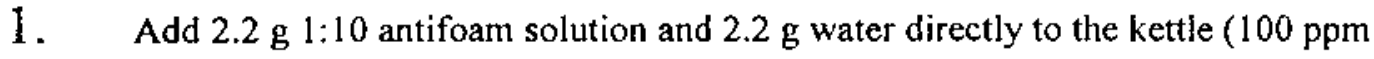
antifoam).

2. Start heating the kettle (Turn on power, setpoint at $93^{\circ} \mathrm{C}$ ). Record the nun data every 20 minutes on the data sheet.

3. Add required quantity of $50 \%$ nitric acid (from the run sheet, Table 4 ) to the kettle.

4. Add required quantity of $90 \%$ formic acid (from the run sheet, Table 4 ) to the kettle.

5. Add $2.2 \mathrm{~g} \mathrm{1:10}$ antifoam solution and $2.2 \mathrm{~g}$ water directly to the kettle $(100 \mathrm{ppm}$ antifoam).

6. Add first addition of CST to the kettle (from the run sheet, Table 4) to the kettle.

7. Add first addition of water to the kettle (from the run sheet, Table 4) to the kettle.

8. Bring kettle contents to boiling.

9. Dewater until kettle volume is approximately $2 \mathrm{~L}$.

10. Add second addition of CST to the kettle (from the run sheet, Table 4) to the kettle.

11. Add second addition of water to the kettle (from the run sheet, Table 4) to the kettle.

12. Bring kettle contents to boiling.

13. Dewater until kettle volume is approximately $2 \mathrm{~L}$.

14. At the end of 30 hours of reflux, turn off the heat to cool the kettle to sub-boiling.

15. Pull a $125 \mathrm{ml}$ sample (SRAT-final) from the kettle, record the weight on the run sheet. Label and send to lab for analyses. 


\section{SME CYCLE}

1. Add $2.2 \mathrm{~g}$ 1:10 antifoam solution and $2.2 \mathrm{~g}$ water directly to the kettle ( $100 \mathrm{ppm}$ antifoam).

1. Add first addition of frit 202 to the kettle (Table 4) to the kettle.

2. Add first addition of formic acid to the kettle (Table 4) to the kettie.

3. Add first addition of water to the kettle (Table 4) to the kettle

4. Bring kettle contents to boiling. Record the run data every 20 minutes on the data sheet.

5. When dewatering is complete, turn off the heat to cool the kettle to sub-boiling.

6. Add second addition of frit 202 to the kettle (Table 4) to the kettle.

7. Add second addition of formic acid to the kettle (Table 4) to the kettle.

8. Add second addition of water to the kettle (Table 4) to the kettle

9. When dewatering is complete, turn off the heat to cool the kettle to sub-boiling.

10. Pull a $125 \mathrm{ml}$ sample (SME-final) from the kettle, record the weight on the run sheet. Label and send to lab for analyses.

11. Stop GC and record the GC time and clock time in the log book. Stop recording run data on the data sheet.

12. Install the calibration gas cylinder to the $\mathrm{GC}$ and run the post-cal check. If the check indicates $\mathrm{OK}$, print a copy and write "post-cal check and run number" on the printout, then place the GC in standby. If the check is not within $10 \%$ of the cal gas composition, notify the engineer.

13. Pump kettle contents into a tared bottle. Record the weight on the run sheet.

14. Complete $\mathrm{pH}$ meter post calibration check. Record measured $\mathrm{pH}$ in $\mathrm{pH} 7$ buffer

15. Instali the outlet flow meter to the purge gas.

16. When the kettle is $\operatorname{cool}\left(<50^{\circ} \mathrm{C}\right)$, record the outlet purge flow in the log book. (All channels).

17. Turn off all instruments. 


\title{
Appendix B - Scope Document Summarizing Planned Testing
}

July 27,1998

SRT-PTD-98-032

To: $\quad$ W. L. Tamosaitis, 773-A

From: L. F. Landon, 704-1T

C. T. Randall, 704-T

\section{SCOPE OF TESTS REQUESTED BY WPT IN SUPPORT OF}

\section{SELECTION PROCESS FOR IN-TANK PRECIPITATION ALTERNATIVE PROCESSES}

\author{
Reference: HLW Technical Request HLE-TAR-98060, CST Ion Exchange, Salt Team Phase 3 \\ Evaluation, 7/14/98.
}

ISCUE 13: Quantify the relative settling behavin of the CST resin in sludge as compared to the current DWPF reference Frit 200.

\section{Objective and Scope:}

One of the four process options to the current In-Tank Precipitation process is the use of nonelutable CST resin to remove the Cs-137 from the supernate fraction of SRS High Level Waste. The loaded resin would be blended with the insoluble solids fraction (sludge) of this waste that is currently being processed in DWPF. It is important to determine if the settling behavior of the CTS resin differs from that of the current DWPF glass former (Frit 200) in DWPF sludge slurries produced throughout the melter feed preparation processes. If the CST resin were to settle in these sludge slurries faster than the Frit 200, slurry homogeneity required for Waste Acceptance, both sampling and melter feeding, may not be met. These tests are "scoping activities" and accordingly do not require the preparation and approval of Technical Task and QA Plans. The quantity of CST resin added to a sludge batch will be based on a CST loading in the glass product of $10-w t \%$.

\section{Researchers:}

Dan Lambert and Gene Daniel

\section{Experimental Method:}


Experiments will be performed using simulated DWPF melter feed containing CST in three particle size distributions. The experiments will determine if, under conditions that promote particle segregation, the CST particles settle more readily or less readily than the reference Frit 200 . If the frit separates more readily than the CST, then the adequacy of existing DWPF agitation for the CTS process will be confirmed. If any of the three CST particle size distributions tested separate more readily than frit, additional tests beyond the scope of this task will be required to better define CST particle size limits, DWPF design modifications, and/or DWPF operating parameters.

The three size distributions to be tested are qualitatively defined as,

- As received (engineered form)

- Extensively crushed resin (to be defined)

- Moderately crushed resin

The size distribution of the CST feed material will be measured for each test.

The CST-bearing melter feed will be produced by carrying out DWPF flowsheet operations at bench scale as outlined in Issue 21 below. The relative settling characteristics of DWPF frit and CST will be evaluated by measuring the ratio of CST to frit in either the solids that settle out under conditions which promote particle segregation or in the overlying depleted slurry.

The rheolugical properties of the melter feed will be measured with a liake viscometer and the rheology will be adjusted by adding or removing water to simulate the lowest DWPF design basis yield stress for sludge process slurries $\left(25 \mathrm{dynes} / \mathrm{cm}^{2}\right)$. The lower yield stress will promote segregation.

Each batch of melter feed (SME product) will be agitated in a beaker with an agitator that is similar to the DWPF SME agitator so it will maximize bulk fluid motion and minimize local shear gradients. To promote segregation, only enough agitation (shear) will be developed to overcome hindered settling. Samples of the settled insolubles and/or the depleted slurry will be obtained as a function of time. The ratio of frit solids to CST solids will be determined by analyzing the samples for titanium and a cation specific to Frit 200.

Preparation and testing will occur in the following order:

- Extensively crushed resin

- Moderately crushed resin

- Resin as received

Slurries produced for this study shall be retained for possible further experiments until released by the Salt Disposition Flowsheet team.

\section{Deliverables:}


- The Frit 200 to CST ratio in settled solids or depleted slurry as function of settling time for each particle size distribution tested.

- Technical report

\section{Pre-Requisites:}

- A run plan will be prepared by ITS for each experiment.

- HLWE to confirm with DWPF-E that these tasks have priority over the current bench-scale R \& D currently in progress or planned in support of DWPF in FY98.

- HLWE to specify whether or not the CST is to be pre-treated with caustic as would be the procedure in preparing the CST for actual use. If the CST is to be pre-treated, HLWE to specify the procedure.

- HLWE to specify whether the CST resin is added to the sludge slurry dry or as a water slurry. If to be added a water slurry, HLWE to specify the wt\% CST in the slurry.

- HLWE to provide ITS any information on the density of the engineered form of the CST.

- HLWE to provide ITS any data on the particle size distribution of the engineered form of the CST.

\section{Data Applicability:}

The tests focus on determining the relative settling characteristics of CST resin as compared to the DWPF glass former (Frit 200) i the melter feed. If there is not a discernable difference in settling characteristics for any of the CST size distributions tested, it would suggest the introduction of CST resin to the SRAT (equivalent to a $10 \mathrm{wt} \%$ concentration in glass) will not adversely impact homogeneity and slurry sampling due to segregation.

However, if it is determined that the CST resin, in any of the tested size distributions, were to settle faster than DWPF Frit 200 it would suggest that additional testing is needed. This testing would not only entail process vessel mixing studies but would also include an assessment of the DWPF sampler to confirm it will obtain a representative sample. These tests could be performed in the fullscale SRAT located at TNX, which contains prototypic DWPF SRAT and SME mixing and sampling systems.

\section{Schedule:}

Technical report issued by $9 / 21 / 98$.

$$
\begin{gathered}
\text { No Longer Categorized O110 per } \\
\text { HI.W-SDT-2001-6011.3 } \\
\text { March 28, 2001 }
\end{gathered}
$$


ISSUE 21:Assess the impact of blending CST resin with sludge in the DWPF Sludge Receipt and Adjustment Tank (SRAT) on the maximum hydrogen generation rate produced during the DWPF melter feed preparation processes.

\section{Objective and Scope:}

One of the four process options to the current In-Tank Precipitation process is the use of nonelutable CST resin to remove the Cs-137 from the supernate fraction of SRS High Level Waste. The resin would be blended with the insoluble solids fraction (sludge) of this waste that is currently being processed in DWPF. It is important to determine if the presence of the CST resin in the DWPF melter feed preparation processes will affect the rate of hydrogen generation from formic acid decomposition. These tests are "scoping activities" and accordingly do not require the preparation and approval of Technical Task and QA Plans. No monosodium titanate solids will be included in the batch. The quantity of CST resin added to a siudge batch will be based on a CST loading in the glass product of $10-w t \%$.

\section{Researchers:}

\section{Dan Lambert and Paul Monson}

\section{Experimental Method:}

Hydrogen generation rates in bench scale versions of the DWPF Slurry Receipt and Adjustment Tank (SRAT) and Slurry Mix Evaporator (SME) will be measured in real time during a SRAT cycle simulation and during a SME cycle simulation. Three experiments will be conducted using the proposed more reducing sludge-only flowsheet and each of the three CST particle sizes provided for Issue 13. The SME product produced in this task will be used as the starting material for each of the three experiments in Issue 13.

A Tank 42 sludge slurry surrogate, containing HM levels of noble metals and mercury, will be used in the tests. The CST will be blended with the SRAT sludge batch prior to beginning the SRAT cycle. Each test will use approximately 2 -Liters of the Tank 42 sludge surrogate. SRAT cycle and SME cycle process simulations will be performed in each test. Samples of the SRAT and SME products will be analyzed for titanium and these results used to validate that the CST content of the product from vitrification of the SME product would be as targeted (10 wt \%). The rheology of the SME product will be measured to determine if the solids concentration needs to be adjusted to obtain the yield stress required for Issue $13\left(25 \mathrm{dynes} / \mathrm{cm}^{2}\right)$.

\section{Deliverables:}

- Quantitative data on hydrogen generation rates (including the peak rate) from the SRAT and SME for each of the three CST size distributions. 
- Results will be compared with existing hydrogen data from previous DWPF process simulations performed under identical processing conditions.

- The calculated CST content of a glass product if the SME product had been verified.

- Technical report

\section{Pre-Requisites:}

- A run plan will be prepared by ITS for each experiment.

- HLWE will confirm with DWPF-E that these tasks have priority over the current bench-scale R \& D currently in progress or planned in support of DWPF in FY98

\section{Data Applicability:}

As currently defined, these tests will only assess the impact that unused CST resin has on the peak hydrogen generation rates previously determined for DWPF for the proposed more reducing sludgeonly flowsheet using Tank 42 sludge surrogate at HM levels of noble metals. The impact of loaded CST resin, containing the level of noble metals projected to be absorbed on the CSI resin during the life expectancy of a CST column, would also need assessed for this option.

\section{Schedule:}

Technical report issued by $9 / 21 / 98$

\section{Approvals:}

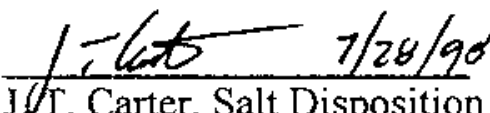

Flowsheet Team

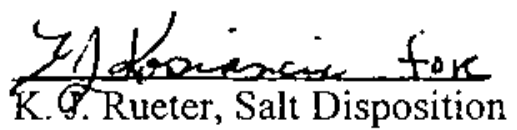

Systems Engineering Team 